\title{
Citizenship and experimental research ${ }^{*}$
}

\section{Cidadania e pesquisa experimental}

\author{
Saul Goldenberg \\ Editor-in-Chief - Acta Cirúrgica Brasileira
}

\section{CITIZENSHIP}

In order to hold citizenship values, one must reaffirm the faith in fundamental human rights, in the dignity and worth of the human person and in the equal rights of men and women and have determined to promote social progress and better standards of life to the community. We should follow the ethic time-honoured medical rule ascribed to Hippocrates: $\underline{\text { Primum }}$ non nocere ("first, do no harm"). And that we shall not do anything to the human being that we would not like to have it done towards each one of us. We are used to listen to some statements in medical congresses as "I had lots of complications in the beginning of procedures, and as time went by, the greater my experience became, the lower my complications were...". We may realize in this public confession that knowledge was increased in the expense of human life. These expressions were understood as crime, during the second World War and Nazis philosophy. Human beings are not experimentation animals and medical knowledge should not be tested upon them. Researches and technical practice must be performed in the experimental surgery laboratory and the "learning curve" shall follow ethical principles to oneself and to the others. The use of the laboratory is directed to the full development of the human knowledge and to the strengthening of respect for human rights.

\section{EXPERIMENTAL}

The word EXPERIMENTAL has a triple meaning:

1) First, Experimental, means, to gain experience, training, drill, schooling, refinement.

Before performing on humans, the surgeon must practice in the surgical experimentation laboratory, in order to follow the Hippocratic aphorism

\section{DO NO HARM.}

Surgical approach consists in the use of "weapons", as an arsenal to surgeons. Therefore, we have a question: where is our shooting drill field? The experimentation lab is the perfect place to manage our weapons and the ideal location to set our learning curve before the "weapon" reaches the human beings. After this initial phase, the presence of a more experienced surgical tutor is indispensable to perform the operative therapy. We must completely assure humans subjected to surgical treatment, concerning the operative technique. Hippocrates was the first to use the word Technic (techne, art, skill) in 460 A.C. "The medical act shall be well done", he said. And Hippocrates used to add: "The physician has to be more than an artisan. He shall have knowledge."
2) The other meaning of the word Experimental, is the practice of making experiments, doing research.

The search for answers and the generation of new concepts. The need to take questions and doubts from private clinic to the experimentation laboratory. Modern surgery is filled with answers and results from laboratory animals. The essential instrument to find these answers obviously is the Scientific method, within its tripod:

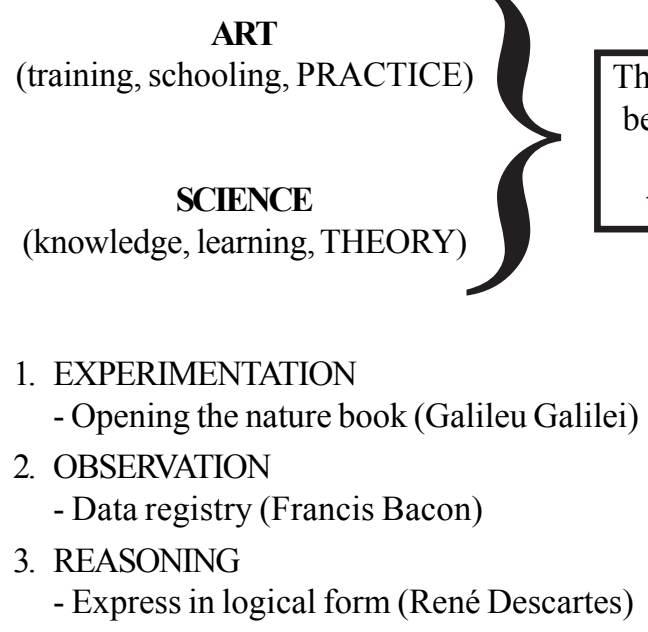

1. EXPERIMENTATION

- Opening the nature book (Galileu Galilei)

2. OBSERVATION

- Data registry (Francis Bacon)

3. REASONING

- Express in logical form (René Descartes)

Descartes (1596-1650) gave us important rules for the Direction of the Mind:

\section{DESCARTESFOUR GOLDEN RULES}

1. Split every difficulty in as many parts as it is necessary so as to better understand them.

2. Array the thoughts from the simple to the more complex.

3. Perform cautious reviews periodically

4. Nothing except the truth shall be considered evident

\section{Avoid subjectivism!!!}

3) Another meaning of the word Experimental is broadcast the acquired experience and communicate the results from the researches. It is essential to publicize the knowledge in meetings and journals

\section{ANON-PUBLISHED AND NON-BROADCASTED KNOWLEDGE MEANS NOKNOWLEDGE. \\ * Article republished with corrections from Acta Cir Bras. 2006;21 Suppl 1:89-90. Available from www.scielo.br/acb}

